\title{
The implication of input data aggregation on upscaling of soil organic carbon changes
}

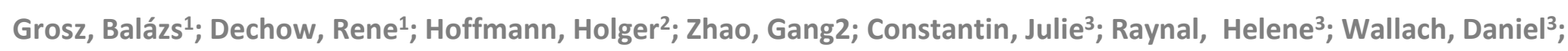
Coucheney, Elsa ${ }^{4}$; Lewan, Elisabet ${ }^{4}$; Eckersten, Henrik ${ }^{5}$; Specka, Xenia ${ }^{6}$; Kersebaum, Kurt-Christian ${ }^{6}$; Nendel, Claas ${ }^{6}$; Kuhnert, Matthias'; Yeluripati, Jagadeesh ${ }^{8}$; Kiese, Ralf9; Haas, Edwin ${ }^{9}$; Klatt, Steffen ${ }^{9}$; Teixeira, Edmar ${ }^{10}$; Bindi, Marco ${ }^{11}$; Trombi, Giacomo ${ }^{11}$; Moriondo, Marco ${ }^{12}$; Doro, Luca ${ }^{13}$; Roggero, Pier Paolo ${ }^{13}$; Zhao, Zhigan ${ }^{14}$; Wang, Enli14; Vanuytrecht, Eline ${ }^{15}$; Tao, Fulu ${ }^{16}$; Rötter, Reimund $^{16}$; Cammarano, Davide ${ }^{17}$, Asseng, Senthold ${ }^{17}$; Weihermüller, Lutz ${ }^{18}$; Siebert, Stefan ${ }^{2}$; Gaiser, Thomas ${ }^{2}$; Ewert, Frank ${ }^{2}$

${ }^{1}$ Thünen-Institute of Climate-Smart-Agriculture, Bundesallee 50, 38116 Braunschweig, DE

${ }^{2}$ Institute of Crop Science and Resource Conservation/Crop Science Group, University of Bonn, Katzenburgweg 5, 53115 Bonn, DE

${ }^{3}$ Equipe MAGE, INRA, 24 Chemin de Borde Rouge - Auzeville CS 5267, 31326 Castanet-Tolosan Cedex, FR

${ }^{4}$ Biogeophysics and water quality, Department of Soil and Environment, Swedish University of Agricultural Sciences, Lennart Hjelms väg 9, 75007 Uppsala, SE

${ }^{5}$ Department of Crop Production Ecology, Swedish University of Agricultural Sciences, Ulls väg 16, 75007 Uppsala, SE

${ }^{6}$ Institute of Landscape Systems Analysis, Leibniz Centre for Agricultural Landscape Research, 15374 Müncheberg, DE

${ }^{7}$ Biological and Environmental Sciences, School of Biological Sciences, University of Aberdeen, 23 St Machar Drive, Aberdeen AB24 3 UU, Scotland, UK

${ }^{8}$ The James Hutton Institute, Craigiebuckler, Aberdeen, AB15 8 QH, UK

9Institute of Meteorology and Climate Research - Atmospheric Environmental Research, Karlsruhe Institute of Technology, Kreuzeckbahnstraße 19, 82467 Garmisch-Partenkirchen, DE

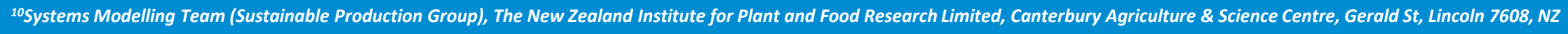

${ }^{11}$ Department of Agri-food Production and Environmental Sciences - University of Florence, Piazzale delle Cascine 18, 50144 Firenze, IT

${ }^{12}$ Marco Moriondo, CNR-Ibimet, Via Madonna del Piano 10, 50019 Sesto Fiorentino, Italy

${ }^{13}$ Desertification Research Group, Universitá degli Studi di Sassari, Viale Italia 39, 07100 Sassari, IT

${ }^{14}$ CSIRO Land and Water, Clunies Ross Street, Canberra, ACT, AU

${ }^{15}$ Division Soil \& Water Management, KU Leuven, Celestijnenlaan 200E, PO 2411, 3001 Heverlee, BE

${ }^{16}$ Climate Impacts Group, Natural Resources Institute Finland (Luke), 00790 Helsinki, FI

${ }^{17}$ Agricultural \& Biological Engineering Department, University of Florida, Frazier Rogers Hall, Gainesville, FL 32611, USA

${ }^{18}$ Institute of Bio- \& Geosciences Agrosphere (IBG-3), Forschungszentrum Jülich, $52425 \mathrm{Jülich}$, DE 


\section{MACSUR Project - Modelling European Agriculture with Climate Change for Food Security}

\section{Scop of the project:}

- How do soil properties (SOC) and yield security interact

- Where are the vulnerable regions for SOC and yield security for climate scenarios

- How does the quality of soil, meteo and managament data affect risk analyses

\section{Crop M group - scaling exercise}

- Integration of biophysical, economic and climate models

- The upscaling of ecological models has resulted in errors and uncertainty that are not determined/quantified.

- Accurate assessment of scaling methods could help in understanding and estimating of the quantity of the error. Therefore it helps to quantify the uncertainty in applying ecological models for larger area. 


\section{Applied models}

\begin{tabular}{|c|c|c|}
\hline DAYCENT & $\begin{array}{l}\text { three different pools, two active pools, a fast, a slow and } \\
\text { a passive pool }\end{array}$ & $\begin{array}{l}\text { The decomposition controlled by modifiers based on } \\
\text { nitrogen availability, soil water content and temperature. }\end{array}$ \\
\hline COUP & $\begin{array}{l}\text { The soil is divided into several organic pools for carbon } \\
\text { and nitrogen. Some of these pools are compulsory while } \\
\text { others can optionally be switched on or off. }\end{array}$ & $\begin{array}{l}\text { Soil moisture, temperature; substrate controlled and } \\
\text { follows first-order kinetics }\end{array}$ \\
\hline HERMES & $\begin{array}{l}\text { The nitrogen pools for mineralization are calculated } \\
\text { based on the Corg content and the } \mathrm{CN} \text { ratio. The } \\
\text { nitrogen pools described below and calculated the Corg } \\
\text { assuming that the } \mathrm{CN} \text { ratio remains constant. }\end{array}$ & $\begin{array}{c}\text { Corg content and the } \mathrm{CN} \text { ratio depending on } \\
\text { temperature and soil moisture, crop residues and } \\
\text { manure. }\end{array}$ \\
\hline MONICA & $\begin{array}{c}\text { Soil carbon dynamics is described using three pairs } \\
\text { (rapid and slow turn-over) of conceptional pools (soil } \\
\text { organic matter, microbial biomass and freshly added } \\
\text { organic matter). }\end{array}$ & $\begin{array}{l}\text { soil temperature and moisture and describe the } \\
\text { environemntal conditions of the simulated site. Microbial } \\
\text { biomass death and respiration rates are additionally } \\
\text { influenced by soil clay content }\end{array}$ \\
\hline STICS & $\begin{array}{l}\text { The fresh organic matter, the microbial biomass and } \\
\text { humified organic matter, the last compartment being } \\
\text { composed of an active and an inert fraction. }\end{array}$ & $\begin{array}{c}\text { C:N ratio, soil temperature and water content, and four } \\
\text { parameters: the humification constant, the } \\
\text { decomposition rate constant of the residues, the decay } \\
\text { rate of the microbial biomass and the assimilation yield } \\
\text { of residue- } \mathrm{C} \text { by the microbial biomass. }\end{array}$ \\
\hline APSIM & $\begin{array}{l}\text { APSIM simulates the SOC in three pools: fresh organic } \\
\text { matter pool (FOM), microbial biomass pool (BIOM), and } \\
\text { humic matter pool (HUM) }\end{array}$ & $\begin{array}{c}\text { Decomposition rates of each pool are mainly influenced } \\
\text { by soil temperature and moisture. }\end{array}$ \\
\hline CENTURY & $\begin{array}{l}\text { three different pools, two active pools, a fast, a slow } \\
\text { and a passive pool }\end{array}$ & $\begin{array}{l}\text { The decomposition controlled by modifiers based on } \\
\text { nitrogen availability, soil water content and temperature. }\end{array}$ \\
\hline
\end{tabular}




\section{Scaling and aggregation steps}

- Resolutions: $1 \times 1 \mathrm{~km}, 10 \times 10 \mathrm{~km}, 25 \times 25 \mathrm{~km}, 50 \times 50 \mathrm{~km}, 100 \times 100 \mathrm{~km}$

- Variable soil properties; constant climate and management ; cropland is assumed to completely cover Nordhrein Westfalia (NUT2).

- Variable climate; constant soil properties and management; cropland is assumed to completely cover Nordhrein Westfalia

- Soil properties: dominant soil

-Weather: mean values

- Scenarios: Nitrogen-water limited, water unlimited, nitrogen-water unlimited

- Time period: 1982-2012

- Modeled crops: maize, wheat 


\section{Soil properties - SOC $30 \mathrm{~cm}(\%)$}
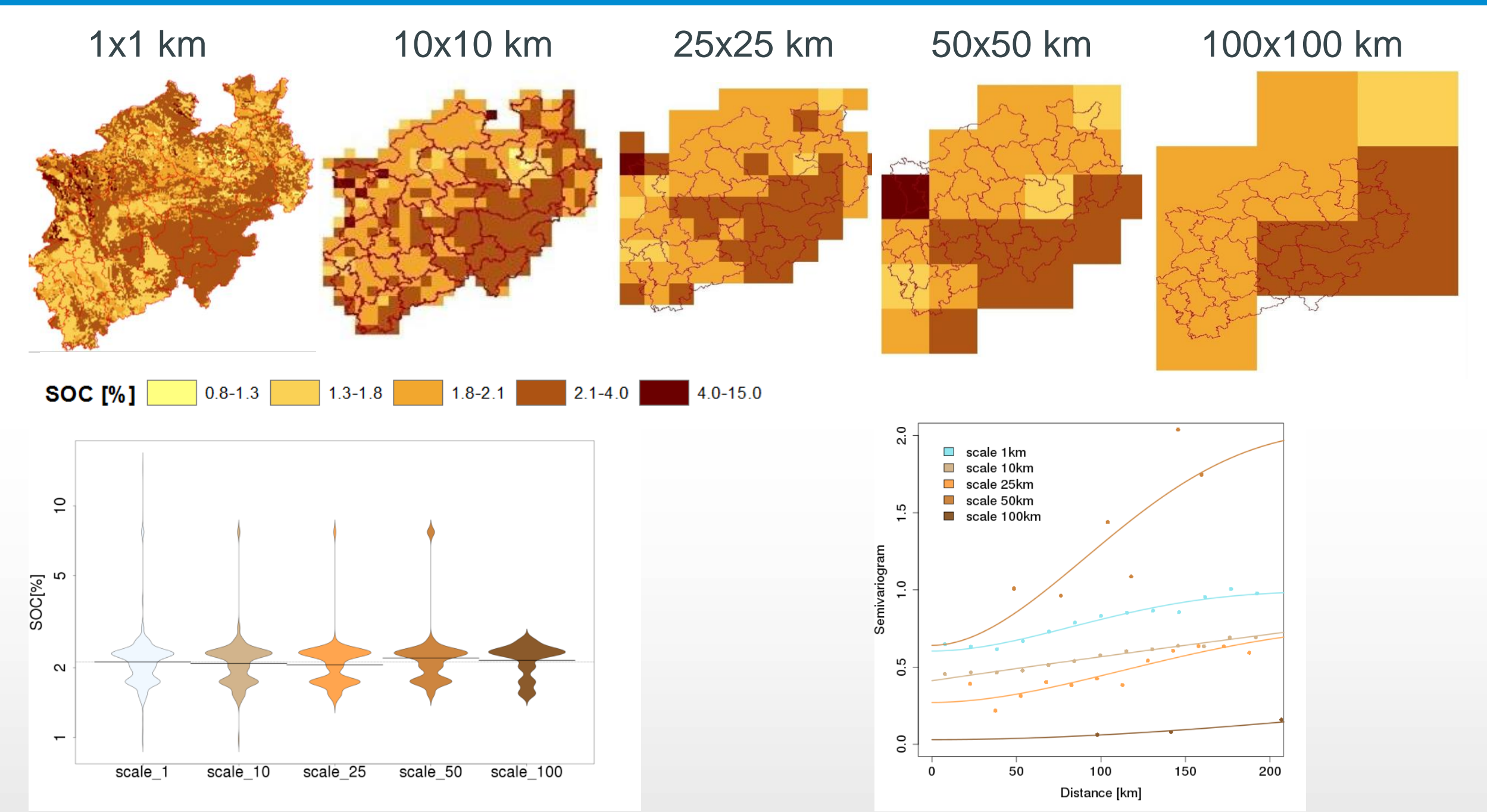


\section{Water content at field capacity}

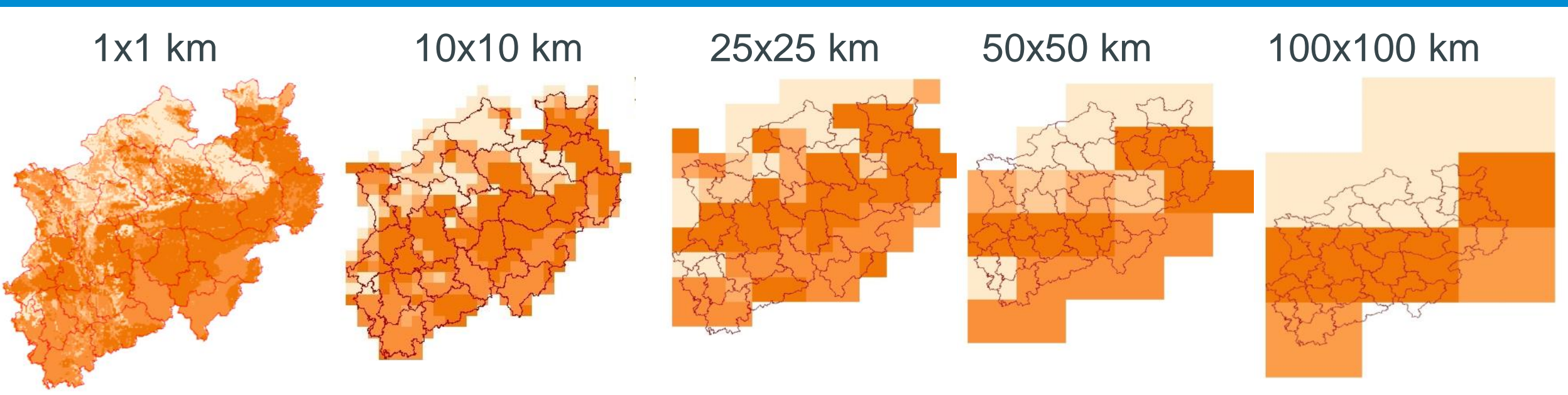

\section{WCFC [1/100]}

$\square 0.1-0.15 \square 0.15-0.2 \square 0.2-0.25 \square 0.25-0.3 \square \square 0.3-0.4$
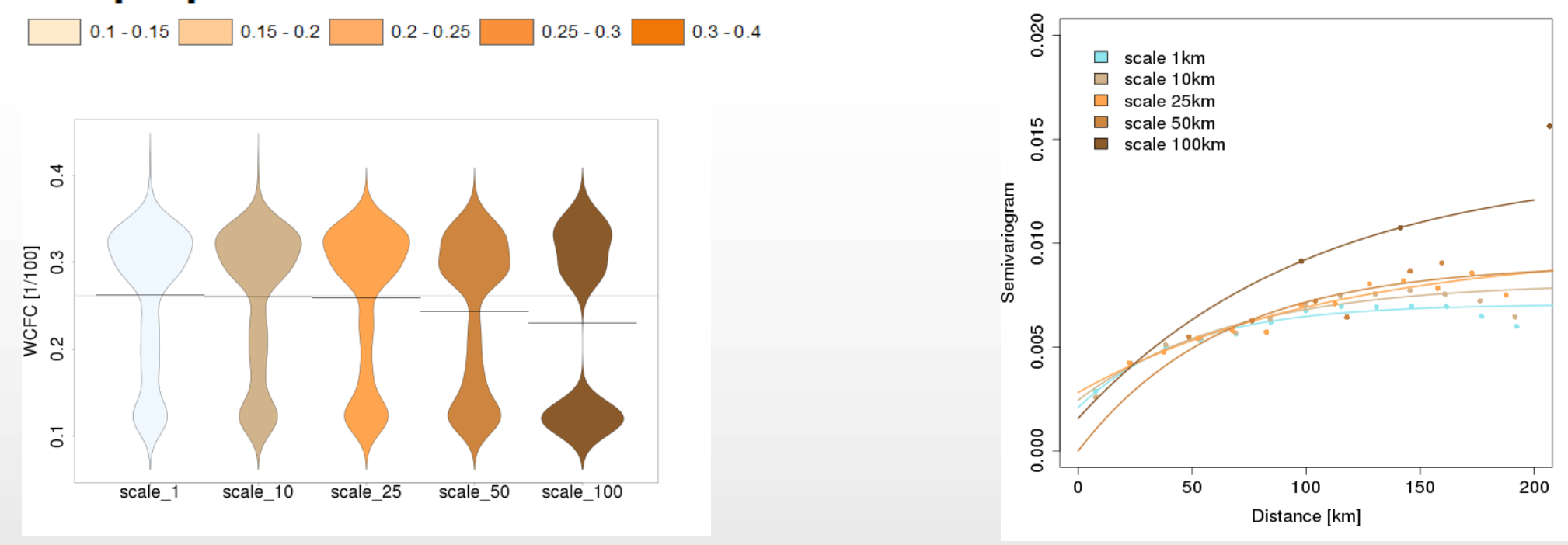


\section{Clay content (\%)}

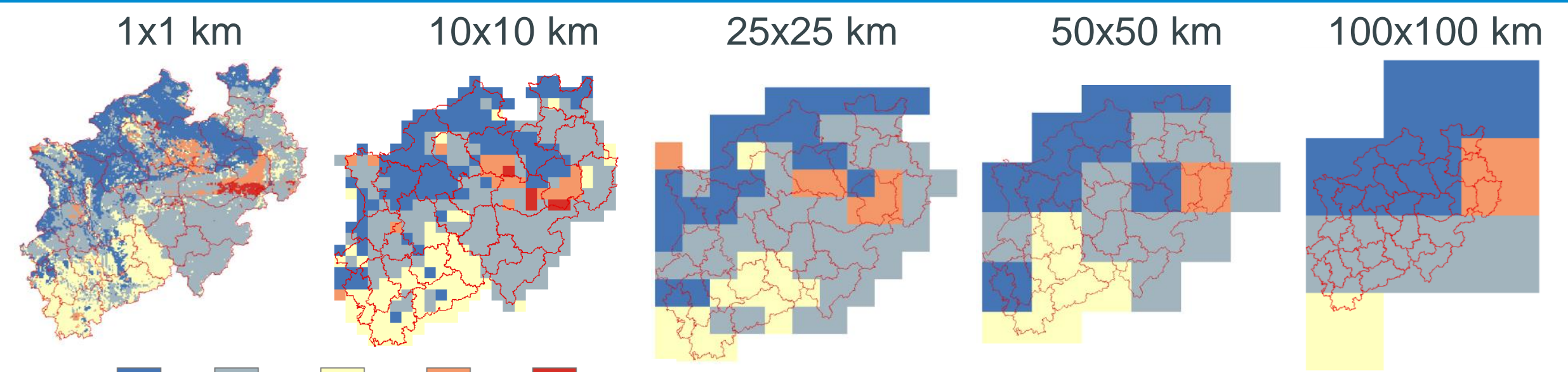

clay [\%] $\square 0-10 \square 10-20 \square 20-30 \square 30-40 \square 40-50$
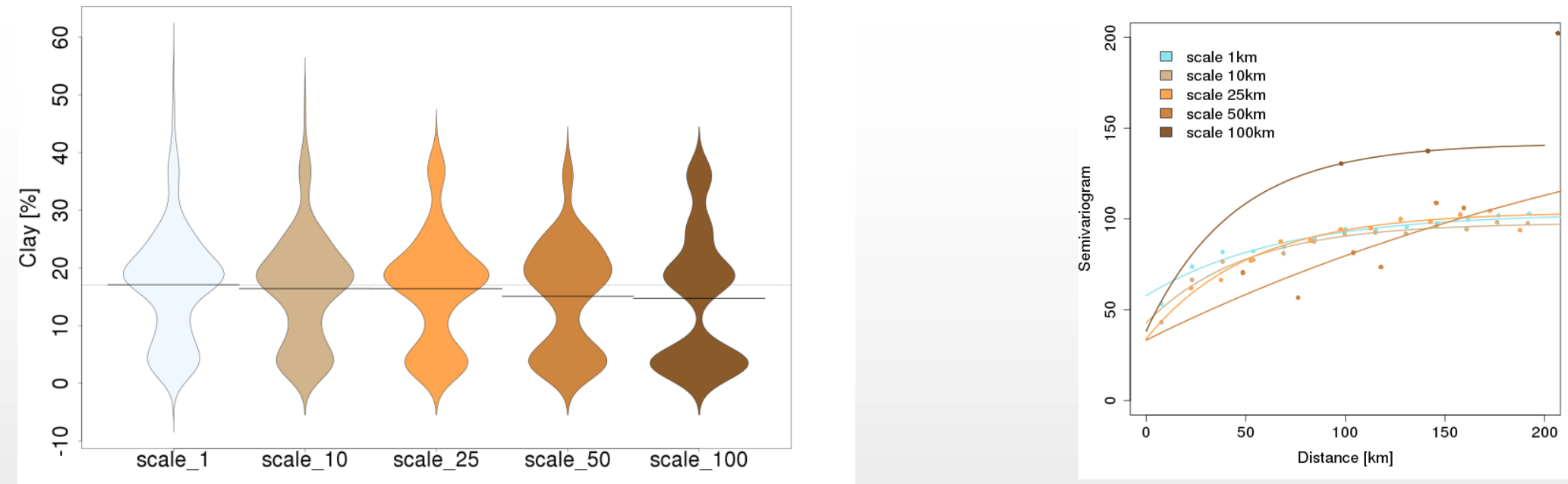


\section{The spatial distribution of the difference of initial}

\section{and final SOC - wheat}
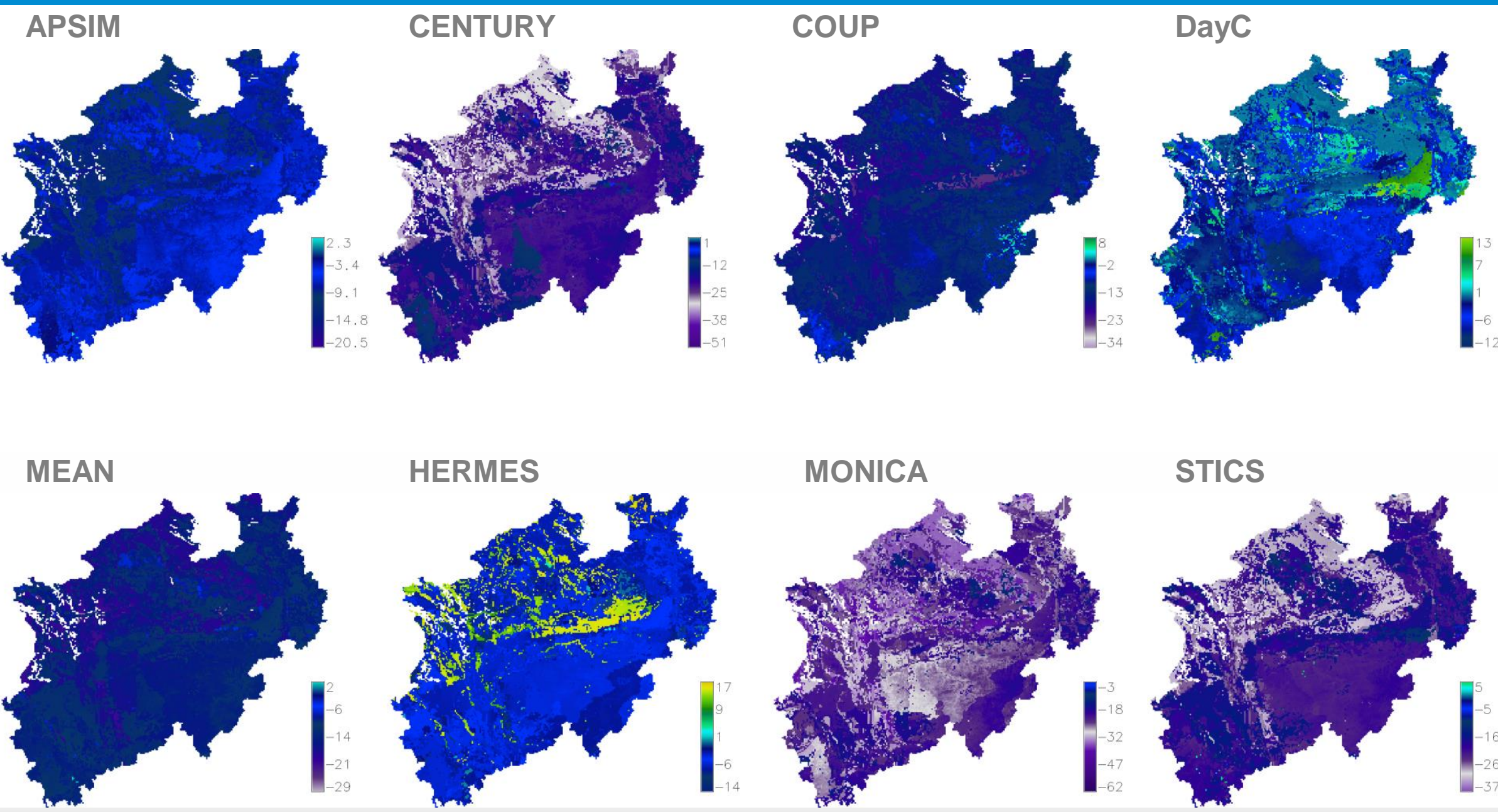


\section{The temporal changes of the SOC for NRW - wheat}

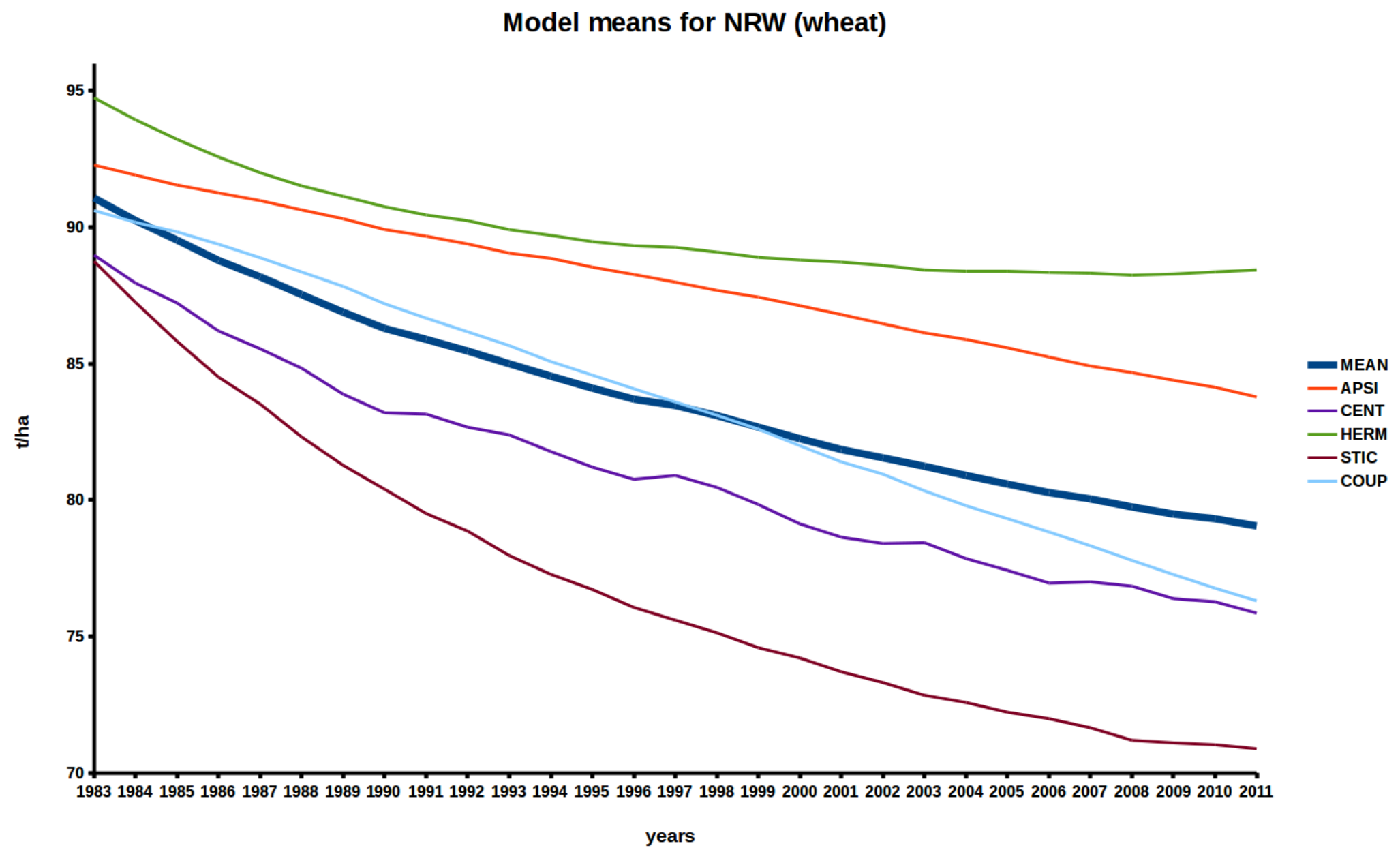




\section{The distribution of the changes of the SOC - wheat}

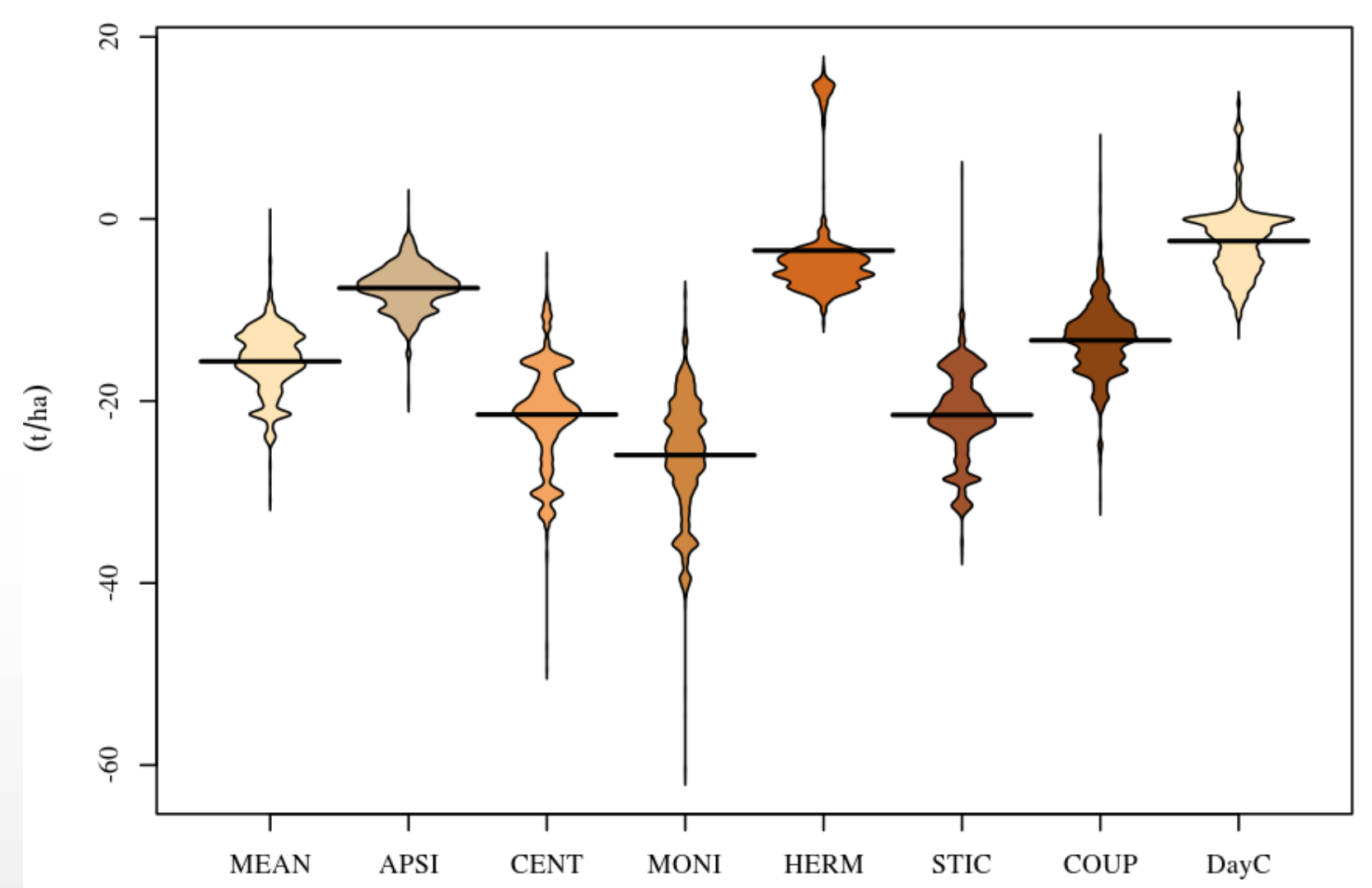




\section{Schematic illustration of disaggregation method and quantification of the data aggregation effects (DAEs). Modified after Zhao et al. (accepted).}
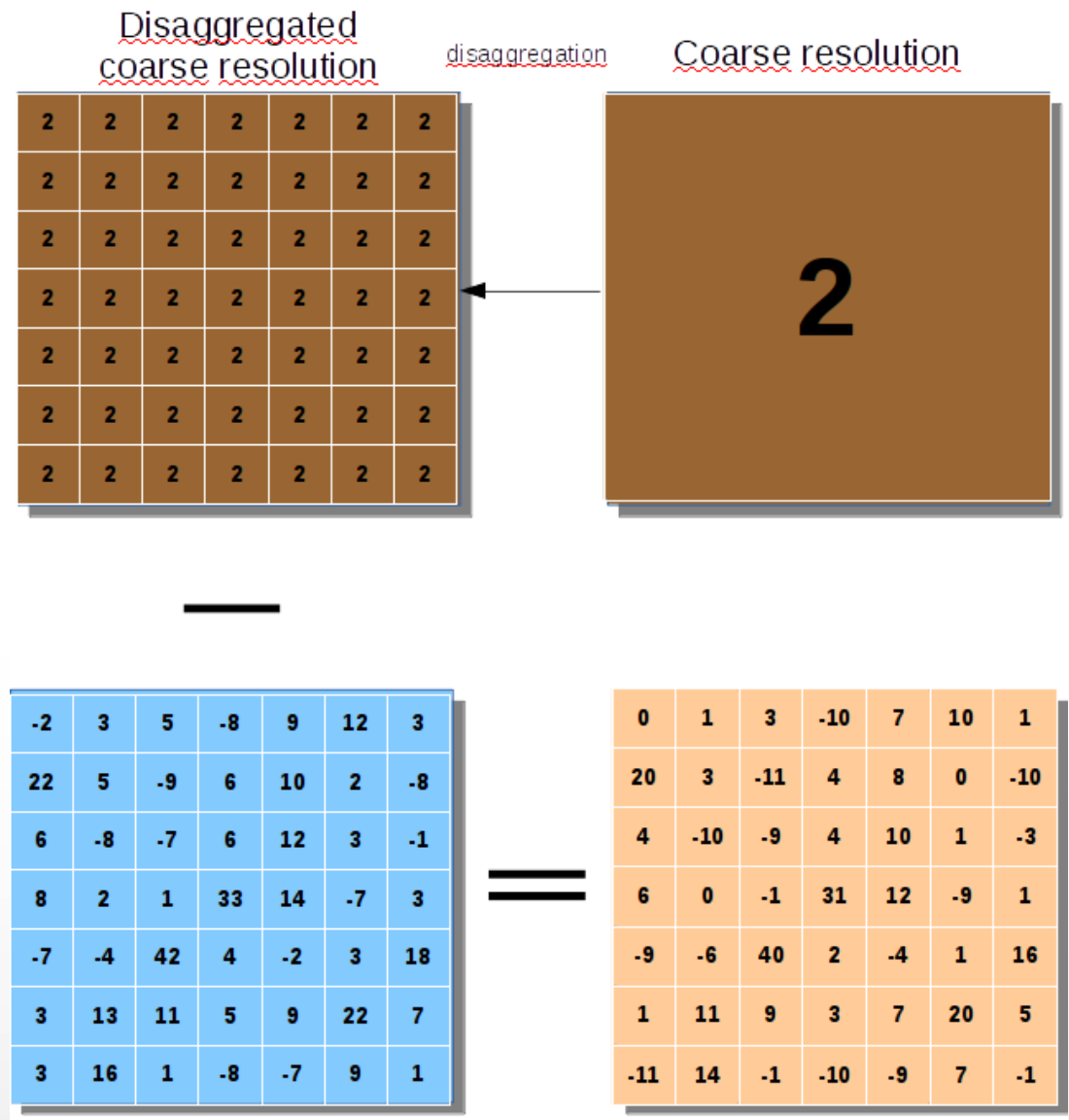

Base scale: fine resolution Calculation scale: original, high resolution

$$
\begin{gathered}
\Delta_{i, j}=D C_{i, j}-O H_{i, j} \\
R M S E_{i}=\sqrt{\frac{\sum_{j=0}^{n} \Delta_{i, j}^{2}}{n}}
\end{gathered}
$$

- $\quad D C_{i, j}$ is the disaggregated values for a specific grid cell

- $\quad \mathrm{OH}_{i, j}$ is the original values (original high resolution, 1 $\mathrm{km}$ resolution) for a specific grid cell

- $\boldsymbol{n}$ is the number of grid cells of the highest resolution

- $\quad \boldsymbol{i}$ indicates different variables

- $\quad j$ indicates different grid cell 

data aggregation effects (DAEs). Modified after Zhao et al. (accepted).

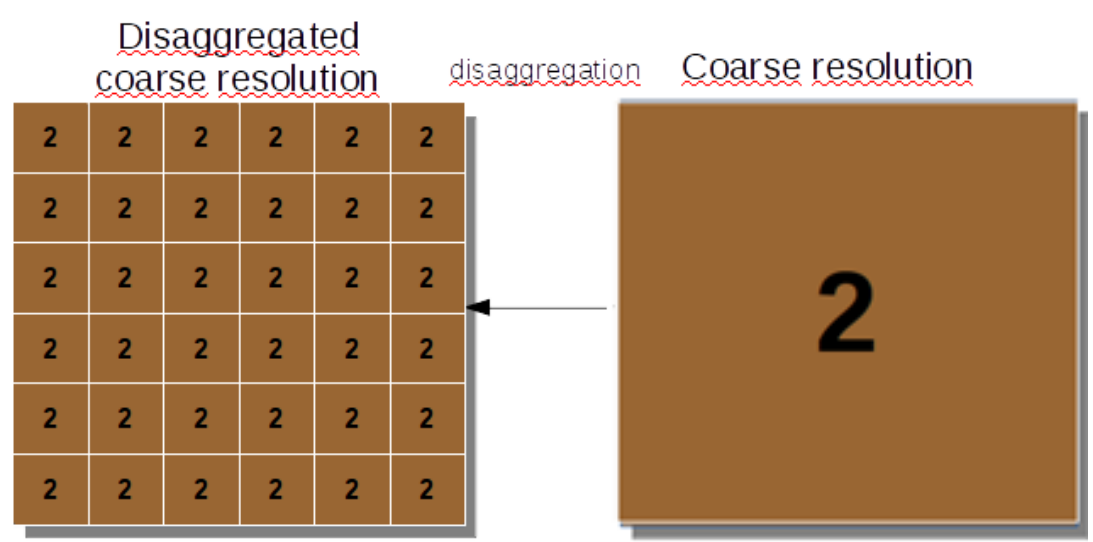

\begin{tabular}{|c|c|c|c|c|c|}
\hline 4 & 4 & 10 & 10 & -1 & -1 \\
\hline 4 & 4 & 10 & 10 & -1 & -1 \\
\hline 6 & 6 & 2 & 2 & 11 & 11 \\
\hline 6 & 6 & 2 & 2 & 11 & 11 \\
\hline-3 & -3 & 7 & 7 & 9 & 9 \\
\hline-3 & -3 & 7 & 7 & 9 & 9 \\
\hline
\end{tabular}

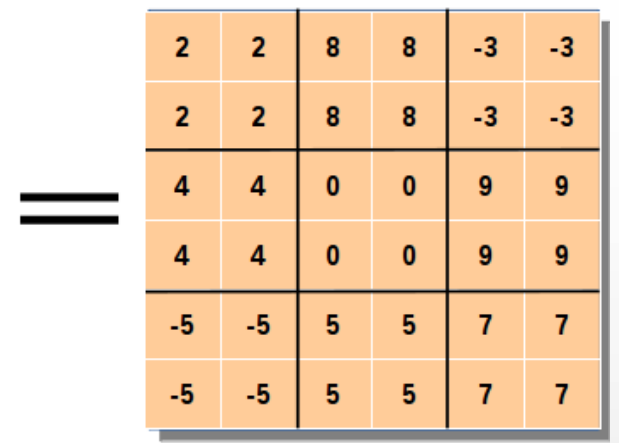

Base scale: fine resolution Calculation scale: courser resolution
$\Delta$

$$
\begin{gathered}
\Delta_{i, j}=D C_{i, j}-O H_{i, j} \\
R M S E_{i}=\sqrt{\frac{\sum_{j=0}^{n} \Delta_{i, j}^{2}}{n}}
\end{gathered}
$$

- $D C_{i, j}$ is the disaggregated values for a specific grid cell

- $\mathrm{OH}_{i, j}$ is the original values (original high resolution, 1 $\mathrm{km}$ resolution) for a specific grid cell

- $\boldsymbol{n}$ is the number of grid cells of the highest resolution

- $\quad \boldsymbol{i}$ indicates different variables

- $\quad j$ indicates different grid cell 


\section{Root-mean-square error, soil aggr., maize, scale of interest:}

\section{$1 \times 1 \mathrm{~km}, 10 \times 10 \mathrm{~km}, 25 \times 25 \mathrm{~km}, 50 \times 50 \mathrm{~km}, 100 \times 100 \mathrm{~km}, \mathrm{NRW}$}

\section{APSIM}

RMSE for SOC at sowing date, $30 \mathrm{~cm}$

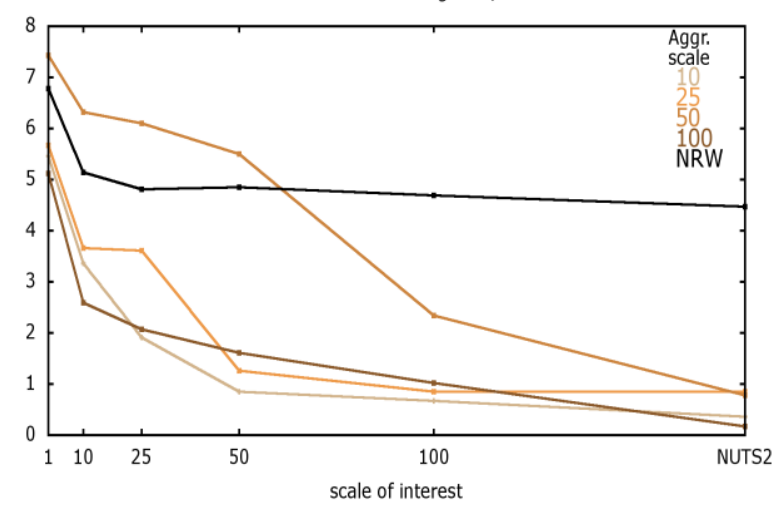

RMSE $_{\text {NRW }}$ of models: $8.346 \mathrm{tC} / \mathrm{ha}$ HERMES

RMSE for SOC at sowing date, $30 \mathrm{~cm}$

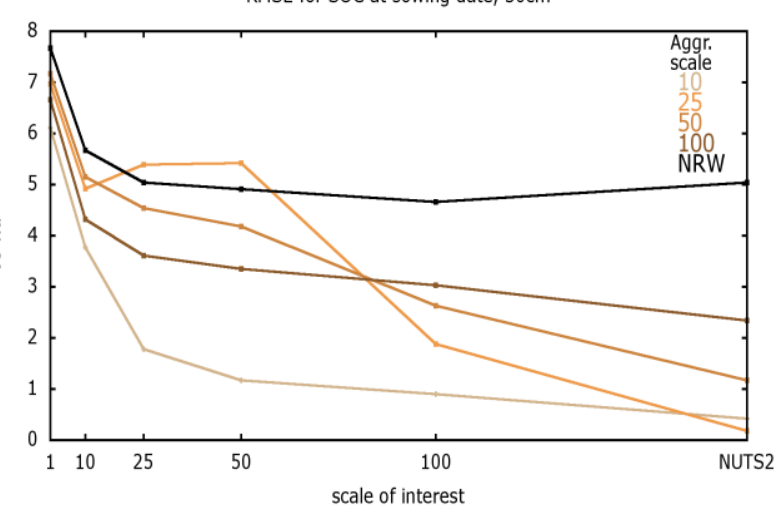

CENTURY

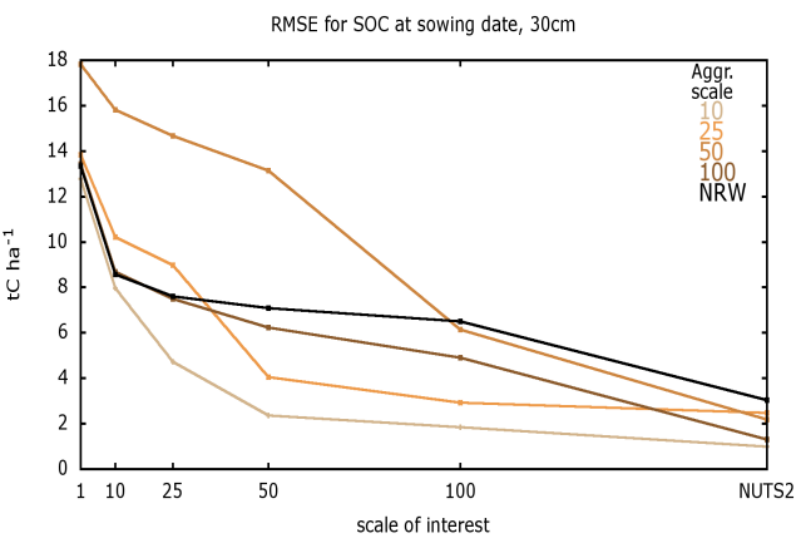

DayC

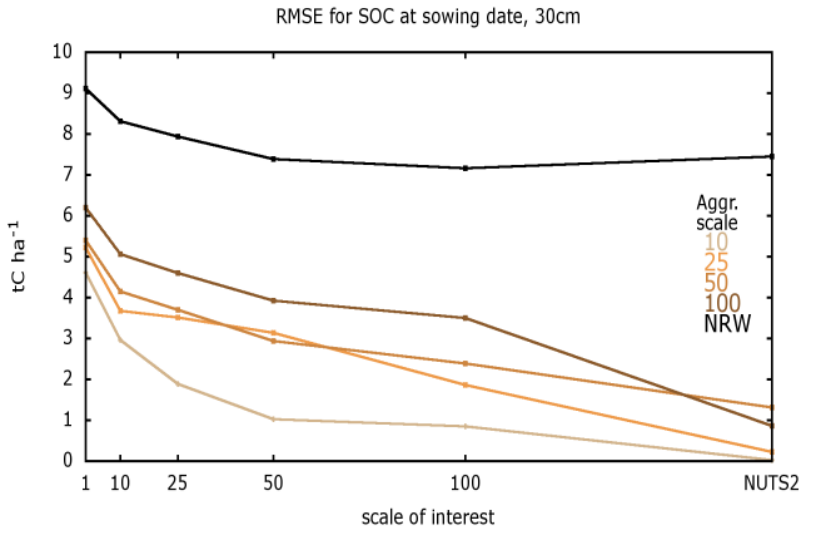

RMSE $_{1 \times 1 \mathrm{~km}}$ of models: $8.931 \mathrm{tC} / \mathrm{ha}$

MONICA

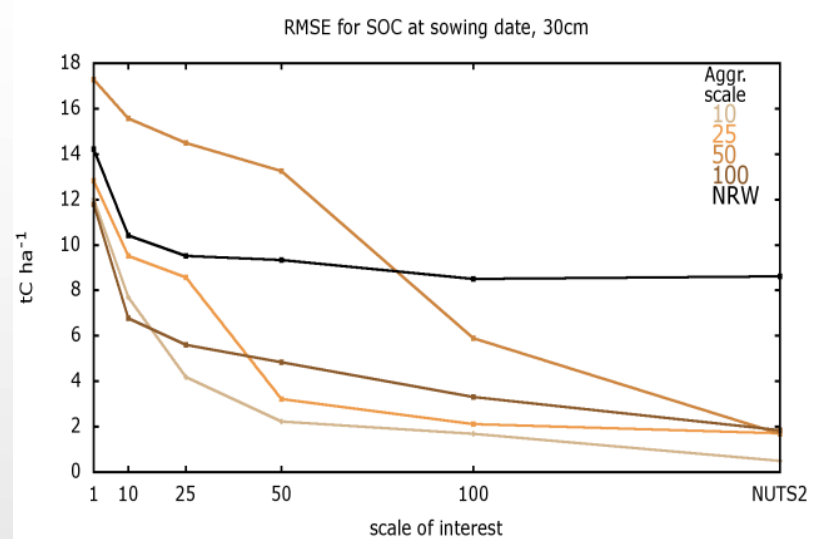

STICS

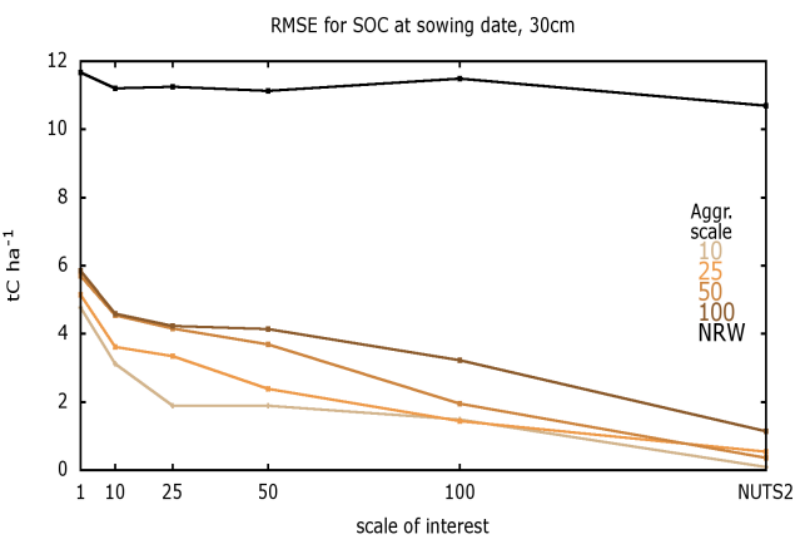




\section{Root-mean-square error, climate aggr., maize, scale of interest:}

\section{$1 \times 1 \mathrm{~km}, 10 \times 10 \mathrm{~km}, 25 \times 25 \mathrm{~km}, 50 \times 50 \mathrm{~km}, 100 \times 100 \mathrm{~km}, \mathrm{NRW}$}

\section{APSIM}

RMSE for SOC at sowing date, $30 \mathrm{~cm}$

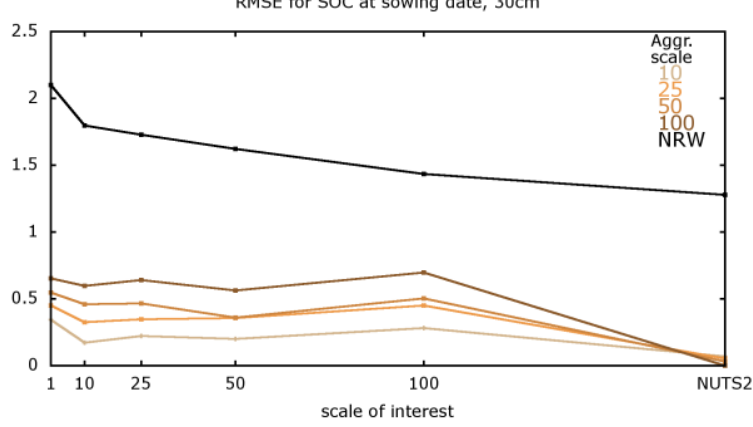

RMSE $_{\text {NRW }}$ of models: $8.346 \mathrm{tC} / \mathrm{ha}$ HERMES

RMSE for SOC at sowing date, $30 \mathrm{~cm}$

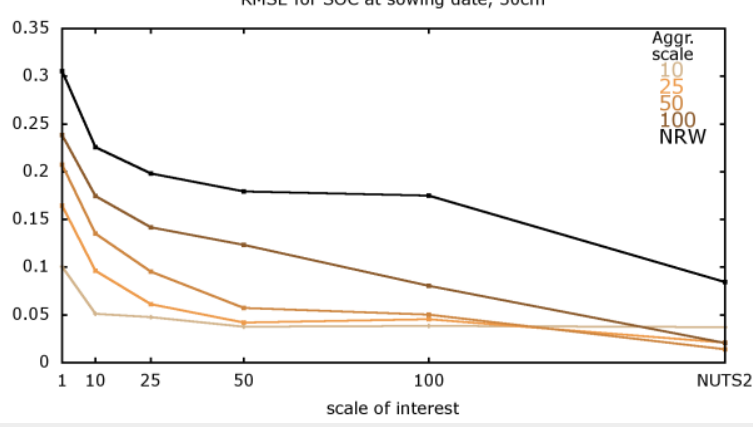

\section{CENTURY}

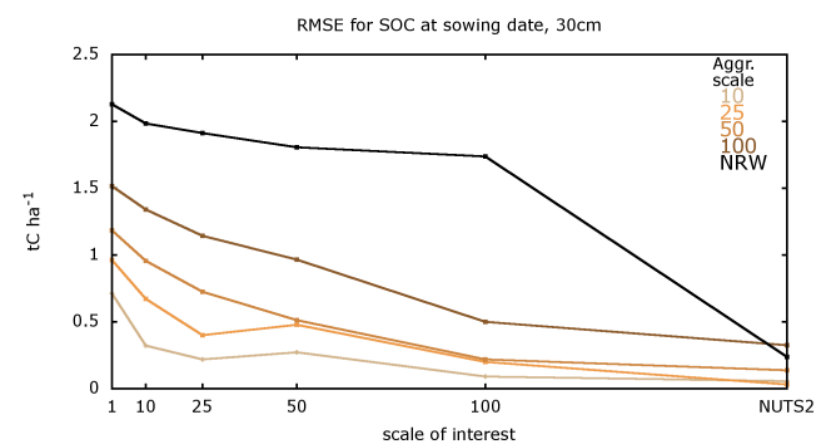

DayC

RMSE for SOC at sowing date, $30 \mathrm{~cm}$

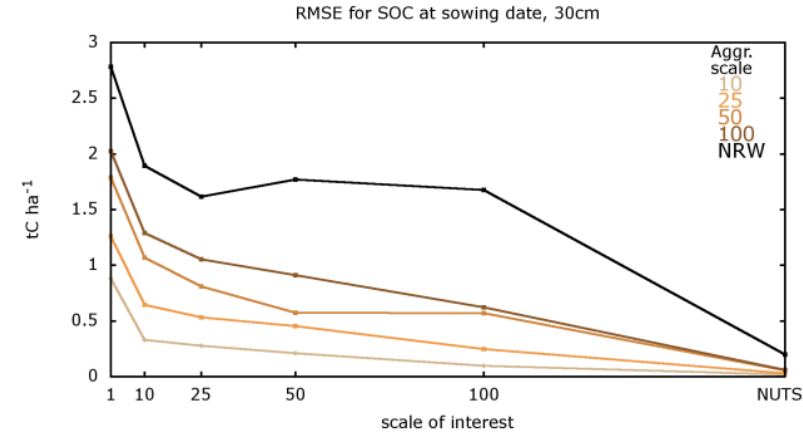

RMSE $_{1 \times 1 \mathrm{~km}}$ of models: $8.931 \mathrm{tC} / \mathrm{ha}$

MONICA

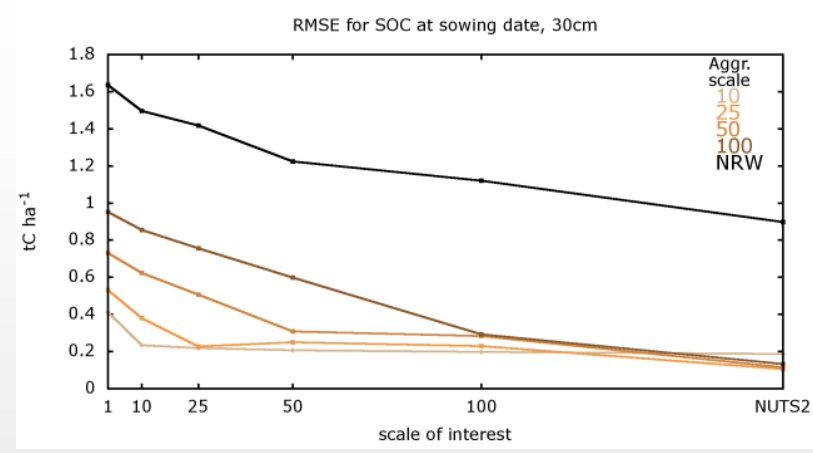

STICS

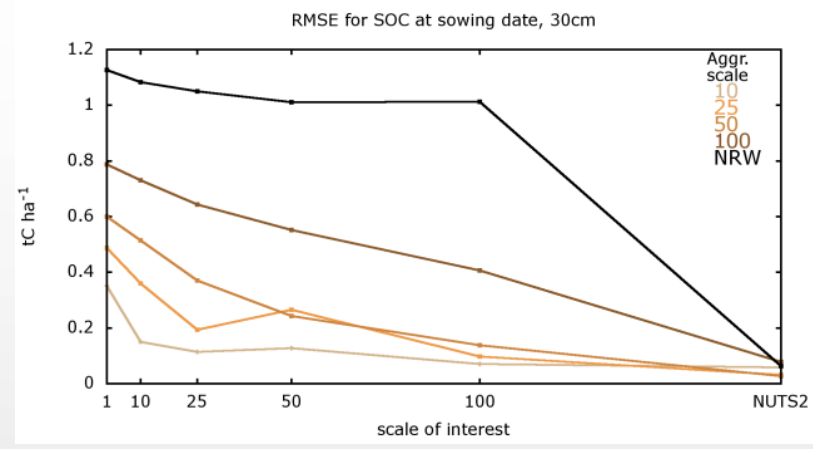




\section{Comparison of the model variability and the uncertainty of}

\section{soil and climate aggregation (aggregation level 10)}

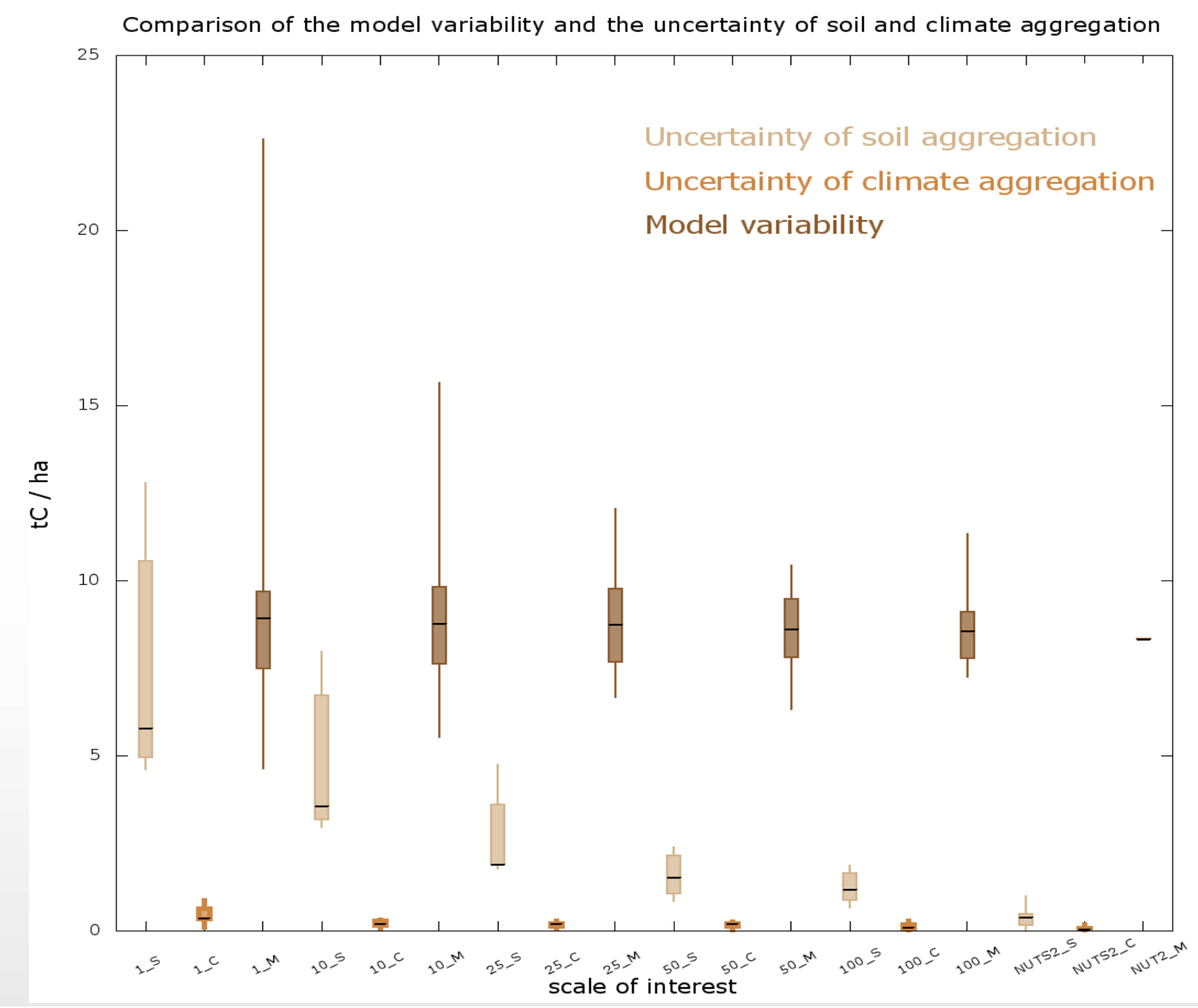


Comparison of the model variability and the uncertainty of

\section{soil and climate aggregation (aggregation level 50)}

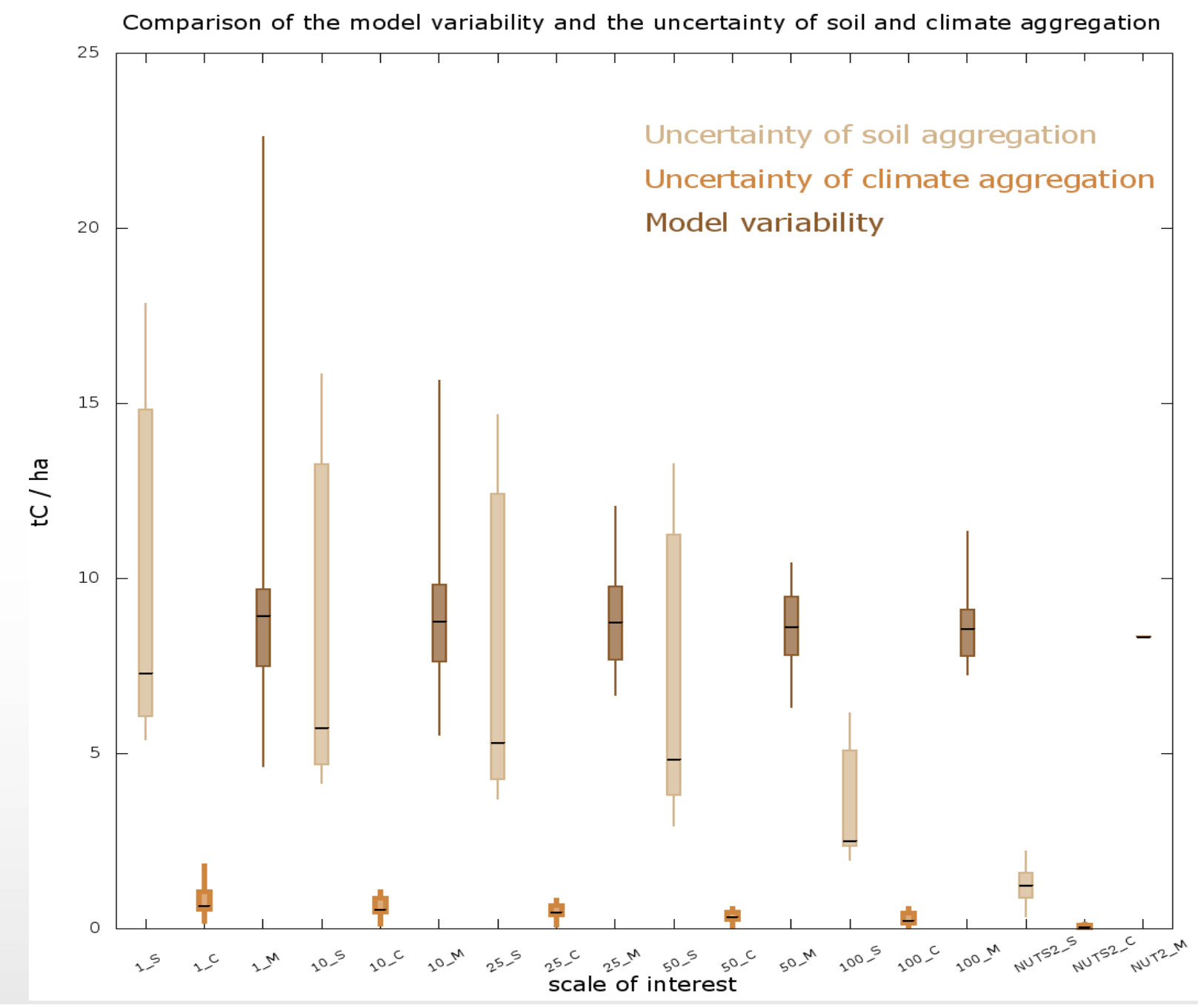




\section{Conclusions}

- The results show that the aggregation of weather data can cause significant, but small regionalization errors in estimating $\mathrm{C}$ stock changes in agricultural soils

- In contrast aggregation errors caused by soil property aggregations are high

- An aggregation of soil properties on $10 \times 10 \mathrm{~km}$ cause less than $20 \%$ regionalization errors in estimating $\mathrm{C}$ stock changes in agricultural soils.

- Aggregation levels at $50 \times 50 \mathrm{~km}$ and $100 \times 100 \mathrm{~km}$ resolution may lead to reliable averages at NUTS 2 level (NRW)

- The scaling exercise shows the high sensitivity of modelled soil organic carbon changes on the accuracy of initial C stocks

- The aggregation procedure is of high relevance for the resulting model error. While weather aggregation by averaging resulted in a continuous decrease of the mean model error from coarse to fine resolution the aggregation of soil information did not. 


\section{Thank you for your attention!}

Acknowledgement

This study was supported by the BMBF/BMELV project on "Modeling European Agriculture with Climate Change for Food Security (MACSUR)" (grant no. 2812ERA115). 


\section{References}

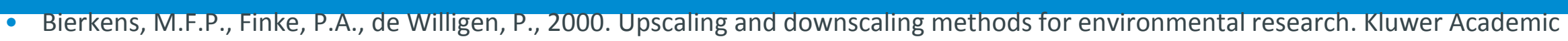
Publisher, Dordrecht the Netherlands, 2000, ISBN 0-7923-6339-6

- Ewert, F., van Ittersum, M.K., Heckelei, T., Therond, O., Bezlepkina, I., Andersen, E., 2011. Scale changes and model linking methods for integrated assessment of agri-environmental systems. Agriculture, Ecosystems \& Environment 142, 6-17.

- Kätterer, T., Bolinder, M. A., Andrén, O., Kirchmann, H., Menichetti, L. (2011) Roots contribute more to refractory soil organic matter than aboveground crop residues, as revealed by a long-term field experiment. Agriculture Ecosystems and Environment. Volume: 141 Number: $1-$ 2, pp 184-192.http://dx.doi.org/10.1016/j.agee.2011.02.02

- Parton, B., Ojima, D., Del Grosso, S., Keough, C. (2001) CENTURY Tutorial. http://www.nrel.colostate.edu/projects/century/century tutorial.pdf

- Parton, W.J., B. McKeown, V. Kirchner, and D.S. Ojima. 1992. CENTURY Users Manual. Colorado State University, NREL Publication, Fort Collins, Colorado, USA.

- Zhao, Gang; Hoffmann, Holger; van Bussel, Lenny G.J.; Enders, Andreas; Specka, Xenia; Sosa, Carmen; Yeluripati, Jagadeesh; Tao, Fulu; Constantin, Julie; Raynal, Helene; Teixeira, Edmar; Grosz, Balázs; Doro, Luca; Zhao, Zhigan; Nendel, Claas; Kiese, Ralf; Eckersten, Henrik; Haas, Edwin; Vanuytrecht, Eline; Wang, Enli; Kuhnert, Matthias; Trombi, Giacomo; Moriondo, Marco; Bindi, Marco; Lewan, Elisabet; Bach, Michaela; Kersebaum, Kurt-Christian; Rötter, Reimund; Roggero, Pier Paolo; Wallach, Daniel; Cammarano, Davide; Asseng, Senthold; Krauss, Gunther; Siebert, Stefan; Gaiser, Thomas; Ewert, Frank (2014) Effect of weather data aggregation on regional crop simulation for different crops, production conditions, and response variables. Climate Research (submitted) 


\section{RMSE}

- RMSE is a frequently used measure of differences between value predected by model or an estimator and the values actually observed.

- The RMSE represent the standard deviation of the differences between predicted and observed values. 